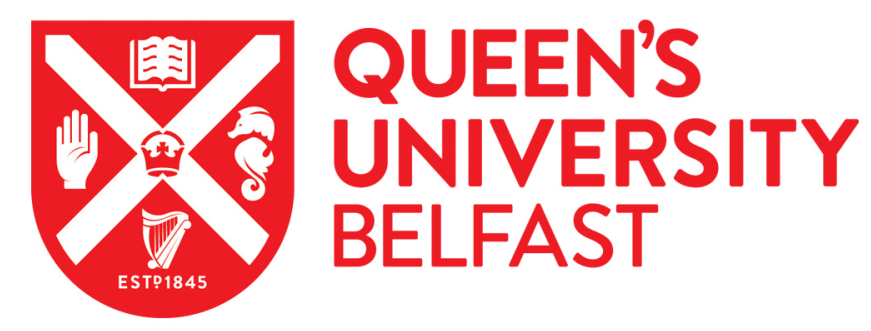

\title{
Introduction to special section: Characterization and monitoring of subsurface contamination
}

\author{
Ntarlagiannis , D., Doherty, R., Costa, R., Williams, K. H., Zhang, C., \& Soupios, P. (2015). Introduction to \\ special section: Characterization and monitoring of subsurface contamination. Interpretation (Society of \\ Exploration Geophysicists), 3(4). https://doi.org/10.1190/INT2015-0917-SPSEINTRO.1
}

\section{Published in:}

Interpretation (Society of Exploration Geophysicists)

\section{Document Version:}

Publisher's PDF, also known as Version of record

\section{Queen's University Belfast - Research Portal:}

Link to publication record in Queen's University Belfast Research Portal

\section{Publisher rights}

(c) 2015 Society of Exploration Geophysicists

\section{General rights}

Copyright for the publications made accessible via the Queen's University Belfast Research Portal is retained by the author(s) and / or other copyright owners and it is a condition of accessing these publications that users recognise and abide by the legal requirements associated with these rights.

Take down policy

The Research Portal is Queen's institutional repository that provides access to Queen's research output. Every effort has been made to ensure that content in the Research Portal does not infringe any person's rights, or applicable UK laws. If you discover content in the Research Portal that you believe breaches copyright or violates any law, please contact openaccess@qub.ac.uk. 


\title{
Introduction to special section: Characterization and monitoring of subsurface contamination
}

\author{
Dimitrios Ntarlagiannis ${ }^{1}$, Rory Doherty ${ }^{2}$, Ralph Costa ${ }^{3}$, Kenneth H. Williams ${ }^{4}$, \\ Chi Zhang ${ }^{5}$, and Pantelis Soupios ${ }^{6}$
}

Subsurface contamination is a significant problem worldwide that directly affects human health, ecosystems, and property. It also can impact valuable resources (e.g., groundwater, surface water, soils). Contaminated sites exist in a variety of sizes and locations, from a leaking underground storage tank to mega sites that stretch across several industrial facilities. Although contamination is primarily the result of anthropogenic activities such as manufacturing, mining, and improper waste disposal, some natural processes can also contribute. This can result in a wide variety of contaminants across a range of concentrations and different media. Subsurface contamination characterization can be challenging because it can occur across a variety of depths, often with no surface footprint. To efficiently address subsurface contamination problems, accurate and high-resolution characterization and monitoring of the contaminant domain is needed.

Subsurface contamination characterization is an inherently difficult task due to the almost endless list of contaminants in a variety of host media and depths. Continuous advances of characterization methods, changes in regulatory standards, and the development of remediation systems further complicate this task. In recent years, novel applications of near surface geophysical methods showed the potential that exists for enhancing subsurface characterization. Electrical geophysical methods have been used in many recent field applications such as hydrocarbon mapping and delineation (Flores Orozco et al., 2012), monitoring enhanced remediation (Williams et al., 2009; Flores Orozco et al., 2011) and natural attenuation (Heenan et al., 2015). A few review papers try to attract attention on methods used as robust monitoring tools (e.g., Slater, 2007; Snieder et al., 2007; Revil et al., 2012) but none have focused on contamination. With this special section we highlight some of the recent advances in the use of geophysical methods for contaminant characterization and monitoring in the subsurface.

The next two manuscripts focus on the use of ground-penetrating radar (GPR). Babcock et al. use GPR, in parallel with conventional geotechnical tools, to investigate the transport mechanism of a subsurface hydrocarbon contaminant in an alluvial depositional environment. The authors demonstrate the potential viability of these tools at contaminated sites, which have complex stratigraphy and therefore may pose problems for other methods used in contaminated site investigations.

The very important problem of ultrathin layers of dense nonaqueous phase liquids (DNAPLs) is investigated by Babcock and Bradford. They use numerical and physical models to examine the suitability of GPR to characterize ultrathin layers of DNAPL trapped at a sand/clay interface. The numerical and physical models are in good agreement, and both show an increase in reflection strength of $10 \%$ or more with partially DNAPLsaturated layer thicknesses as low as $1 / 50^{\text {th }} \lambda$.

The following two manuscripts are focused on common electrical methods, including resistivity, induced polarization (IP) and self potential (SP). Mendonça et al. use resistivity and IP, supported by geochemical and microbiological data, for enhanced site characterization; the synergistic interpretation of the geophysical data, with the geochemical and metagenomic data allowed the detailed characterization of gas fluxes in the subsurface. The conceptual model developed suggests that biogas trapped in the subsurface can rapidly travel to the surface.

Doherty et al. use the promising SP method to monitor natural attenuation of gasworks contamination in groundwater. Large SP anomalies are linked to electro-

\footnotetext{
${ }^{1}$ Rutgers University-Newark, Department of Earth and Environmental Sciences, Newark, New Jersey, USA. E-mail: dimntar@scarletmail.rutgers .edu.

${ }^{2}$ Queens University-Belfast, School of Planning, Architecture and Civil Engineering, Belfast, UK. E-mail: r.doherty@qub.ac.uk.

${ }^{3}$ Weston Solutions, Inc., Raleigh — Durham, North Carolina, USA. E-mail: Ralph.Costa@WestonSolutions.com.

${ }^{4}$ Lawrence Berkeley National Laboratory, Earth Sciences Division, Berkeley, California, USA. E-mail: khwilliams@lbl.gov.

${ }^{5}$ Kansas University, Department of Geology, Lawrence, Kansas, USA. E-mail: chizhang@ku.edu.

${ }^{6}$ Technological Educational Institute of Crete, Department of Environmental and Natural Resources Engineering, Chania, Hellas. E-mail: soupios@staff.teicrete.gr.

Published online 21 October 2015; corrected version published online 27 October 2015.This paper appears in Interpretation, Vol. 3, No. 4 (November 2015); p. SABi-SAB2.

http://dx.doi.org/10.1190/INT2015-0917-SPSEINTRO.1. @ 2015 Society of Exploration Geophysicists and American Association of Petroleum Geologists. All rights reserved.
} 
chemical and redox processes at the edge of the groundwater plume that are dominated by microbially mediated reactions.

The next manuscript utilizes magnetic methods for environmental investigations. Kokinou studies the magnetic properties (magnetic susceptibility [MS] and temperature dependence of the MS) of near-surface soils in an environmental protected area. The differences in the spatial distribution of the magnetic properties identified the potential suggesting anthropogenic and natural sources for contamination in the Natura (EU, 2015) (environmentally protected) study area.

\section{References}

EU, 2015, Natura 2000 network, http://ec.europa.eu/ environment/nature/natura2000/index_en.htm, accessed 1 September 2015.

Flores Orozco, A., A. Kemna, C. Oberdörster, L. Zschornack, C. Leven, P. Dietrich, and H. Weiss, 2012, Delineation of subsurface hydrocarbon contamination at a former hydrogenation plant using spectral induced polarization imaging: Journal of Contaminant Hydrology, 136-137, 131-144, doi: 10.1016/j.jconhyd.2012.06 .001 .

Flores Orozco, A., K. H. Williams, P. E. Long, S. S. Hubbard, and A. Kemna, 2011, Using complex resistivity imaging to infer biogeochemical processes associated with bioremediation of an uranium-contaminated aquifer: Journal of Geophysical Research, 116, 1-17, doi: 10.1029/ 2010JG001591.
Heenan, J., L. D. Slater, D. Ntarlagiannis, E. A. Atekwana, B. Z. Fathepure, S. Dalvi, C. Ross, D. D. Werkema, and E. A. Atekwana, 2015, Electrical resistivity imaging for long-term autonomous monitoring of hydrocarbon degradation: Lessons from the Deepwater Horizon oil spill: Geophysics, 80, no. 1, B1-B11, doi: 10.1190/geo20130468.1.

Revil, A., M. Karaoulis, T. Johnson, and A. Kemna, 2012, Review: Some low-frequency electrical methods for subsurface characterization and monitoring in hydrogeology: Hydrogeology Journal, 20, 617-658, doi: 10 .1007/s10040-011-0819-x.

Slater, L., 2007, Near surface electrical characterization of hydraulic conductivity: From petrophysical properties to aquifer geometries - A review: Surveys in Geophysics, 28, 169-197, doi: 10.1007/s10712-007-9022-y.

Snieder, R., S. Hubbard, M. Haney, G. Bawden, P. Hatchell, and A. Revil, and DOE Geophysical Monitoring Working Group, 2007, Advanced noninvasive geophysical monitoring techniques: Annual Review of Earth and Planetary Sciences, 35, 653-683, doi: 10.1146/annurev .earth.35.092006.145050.

Williams, K. H., A. Kemna, M. J. Wilkins, J. Druhan, E. Arntzen, A. L. N'Guessan, P. E. Long, S. S. Hubbard, J. F. Banfield, and A. L. N. Guessan, 2009, Geophysical monitoring of coupled microbial and geochemical processes during stimulated subsurface bioremediation: Environmental Science and Technology, 43, 6717-6723, doi: 10 .1021/es900855j. 